\title{
LUIS ALBERTO DE CUENCA: NECESIDAD DEL HÉROE
}

\author{
Diego Valverde Villena
}

\section{Von Mrthos zum Logos}

En el principio era la Palabra. Y con ella, el mito. O quizás antes de ella, preparándola, pidiéndola, necesitándola para expresarse. La Palabra y el Mito naciendo de la misma chispa, ungiéndonos bajo su doble especie para hacernos humanos, confiriéndonos la mirada del dios. Palabra y Mito, caminando juntos en el principio de los tiempos, en el tiempo sin tiempo de la épica.

Ese tiempo intemporal de la literatura es el tiempo que rige la obra de Luis Alberto de Cuenca. Tal como el Dios de Boecio capta la eternidad de un golpe (tota simul et perfecta possessio), De Cuenca - que nunca ha dejado de ser aquel niño rodeado de libros - comparte, a la vez, la vida y las andanzas de los héroes de toda época. El niño De Cuenca nos habla repetidas veces de esa fuerte presencia de los héroes en su vida, codo con codo con él en cada una de las acciones que la vida nos depara: "la vida... se alimenta en lo fundamental 
de recuerdos librescos, de modo que no sé si las cicatrices que ennoblecen mi alma es un producto de heridas propias o de sueños ajenos". ${ }^{1}$

No importa el nombre o el aspecto: puede ser Dillinger, el Guerrero del Antifaz, Steve McQueen en The Getaway, Flash Gordon o el Príncipe Valiente...2 lo que perdura es el individualismo intemporal del héroe. La búsqueda de uno mismo a través del viaje multiforme, dentro y fuera de nosotros. La interna escala de ascensión del héroe. "The pursuit of honour through risk", en frase de Bowra, que De Cuenca ha adoptado como mote de su blasón.

$Y$, en el fondo, dos cosas: una, el enfrentamiento con uno mismo, la victoria (que también es derrota) frente al alter ego. La batalla que no se puede vencer, como saben Gilgamesh y Arjuna. También, como saben ambos, la victoria que está en el hecho de presentar batalla. Y la otra: la lucha entre el Bien y el Mal.

La Luz y las Tinieblas, con su constante lucha, están en todo, como bien prefiguró Mani. El mito es testigo y cronista de esa lucha desde que el mundo era joven. Y no es fácil escoger bando: a menudo los términos se confunden. Particularmente en nuestra época, que abjura de los héroes y los rebaja. Es el relativismo moral lo que triunfa ahora, y ya no hay buenos ni malos. Tampoco hay sitio para los héroes, para campeones ni paladines. Cuántas veces hemos oído comentarios despectivos o rencorosos hacia quienes hacen las cosas demasiado bien o con gran facilidad (que sus nombres sean Velázquez o Induráin, que su ámbito sea el Arte o el Deporte, es secundario).

Heráclito seduce con sus oscuras palabras, y las canciones de opósitos con la magia del oxímoron, pero Luis Alberto de Cuenca pregunta al niño en su interior y a él se encomienda. Entonces surge desde dentro esa religiosidad auténtica, esa unción infantil, ese poder divino y candoroso que encontramos en los niños de Saki y en la niña del Ordet de Dreyer. Ahí se rompe la duda. El héroe toma sus armas y sale al campo. La victoria y la derrota son dos espejismos, dos caras de la misma moneda, no importan. Mirad sólo las divisas que porta el caballero poeta: son el Mito y la Palabra.

\section{EL HÉROE ENCARA SU NOMBRADÍA}

Nombres, siempre nombres propios. Citados, glosados, aludidos, sugeridos con una palabra, con un guiño. Nombres reflejados en Los Retratos

1. L. A. de Cuenca, "Piratas", $A B C, 20$ de diciembre de 1997.

${ }^{2} C f$. los varios artículos de L. A. de Cuenca en Prohemio, en los primeros 70. 
(que primero se iba a llamar Galería), que a su vez dibujan el perfil del autor. Una cascada de nombres abre Elsinore, y prefigura el aluvión de nombres que poblará los laberintos del palacio danés, tejidos sobre el tetragrámaton amoroso de Rita, mutado en Arit para evitar la profanación por parte del no iniciado; para que sólo el acólito llegue al sancta sanctorum y desde allí, desde ese Aleph, el centro de Elsinore, contemple a todos los personajes allí presentados: los admirados y emulados por Luis Alberto de Cuenca, los que acapara su mirada, los que dejan vislumbrar su verdadero rostro.

Nombres propios, palpitantes y llenos de vida. Símbolos, y también mucho más que símbolos. Héroes individuales, condenados a la soledad y a la separación por su propia grandeza, por su diferencia. Seres marginales por excelencia. ${ }^{3} \mathrm{Y}$ en esas huestes, donde la valentía es lema, cabalga Luis Alberto de Cuenca: "Seguiré siendo un marginado mientras me sigan fascinando los nombres propios", dice en una de sus poéticas. ${ }^{4}$ Ellos son sus aliados, sus compañeros. Los que forman una barrera frente a la rutina; a los que negará (negándose a sí mismo) una vez, sin embargo, para conseguir la pírrica victoria de una noche de ronda, el exiguo botín de una mujer de las que no saben volar, que diría Girondo: "Ahora sabes que a ellas / les aburren los tipos llenos de nombres propios".

\section{LOS VALIENTES ANDAN SOLOS}

Ecce heros. Ahí tenéis a Kirk Douglas cabalgando en blanco y negro, huyendo más del mundo hostil que lo ha arrinconado (a él y a su época), que de un Walter Matthau que lo admira. Ya no es el felino solitario y errabundo de A Man without a Star. Ahora es el héroe de un lugar que ignora a los héroes. Lonely are the Brave titula esta cinta Dalton Trumbo, un director que supo bien de las variantes de la soledad.

Ese es el héroe de nuestro tiempo. El que abraza su destino solitario. El que sigue su propio camino. Aunque ello le cueste la marginalidad en un mundo que pondera a resentidos, antihéroes y tramposos.

\footnotetext{
3. Cf. el comentario a marginalidades heroicas, como Stefan George y Julio Martínez Mesanza en "Stefan George" dentro de El héroe y sus máscaras, Mondadori, Madrid 1991, 215-218.

${ }^{4}$ L. A. de Cuenca, "Poética”, en C.G. Moral, R.M. Pereda (ed.) Joven poesía española, Cátedra, Madrid, 1993, 351.

${ }^{5}$ L. A. de Cuenca, “Noche de ronda”, en El otro sueño, Renacimiento, Sevilla 1987, 55.
} 
Luis Alberto de Cuenca sabe todo eso, y lo asume. Sabe que su camino es solitario, pero es el suyo. Se enfrenta a lo pusilánime, a la ambigüedad, a lo políticamente correcto. ${ }^{6}$ No puede dejar de ser un héroe, aunque viva "en un lugar muy triste que ha prohibido los héroes". ${ }^{7}$ Sabe cuál es el pago de su actitud, la recompensa de sus hazañas, el destino que le espera. De ahí surgirá la fuente de su canto: "un grito (o un susurro) de angustia / y soledad". ${ }^{8}$

Pero eso no le importa. Cabalga feliz, y disfruta de la pelea y del canto, llenando todos sus actos de joi, como su compañero Guillermo de Aquitania. El mismo talante heroico lo aplica De Cuenca a todos los aspectos de su vida. La imagen que explica lo que entiende por poesía también explica "lo que entiendo por amor, por coraje, por amistad, por juego". ${ }^{9}$

Frente a la rutina, las consignas y el relativismo moral y estético (dos variantes de lo mismo), el temperamento heroico sigue dando hospitalidad al mito y la palabra. Luis Alberto de Cuenca sabe que siguen siendo válidas las palabras de Shelley: ${ }^{10}$ "... ser / bueno, grande y alegre, hermoso y libre; / sólo eso es Vida, Alegría, Poderío y Victoria".

\footnotetext{
6.. L. A. de Cuenca, "Amor sin barreras", ABC, 23 de enero de 1998.

${ }^{7}$ L. A. de Cuenca, “España”, en El otro sueño, 50.

${ }^{8}$ L. A. de Cuenca, "Advertencia al lector", en Por fuertes y fronteras, Visor, Madrid 1996, 33.

${ }^{9}$ L. A. de Cuenca, "Poética”, en op. cit., 351.

${ }^{10}$ Percy Bysse Shelley, también transgresor, también marginal, también héroe: ¿será que en el fondo todos los tiempos han sido malos para los héroes?
} 